\title{
CHFR Promoter Methylation
}

National Cancer Institute

\section{Source}

National Cancer Institute. CHFR Promoter Methylation. NCI Thesaurus. Code C128659.

An epigenetic modification involving methylation of $\mathrm{CpG}$ islands in the promoter region of the CHFR gene. 